\title{
Analysis of air pollution caused by mass transportation design changes
}

\author{
Budiman Napitupulu ${ }^{2}$, Ismiyati Ismiyati ${ }^{1, *}$, and Mudjiastuti Handajani ${ }^{3}$ \\ ${ }^{1}$ Civil Engineering Department, Diponegoro University, Indonesia \\ ${ }^{2}$ Civil Engineering Department, Diponegoro University, Indonesia. \\ ${ }^{3}$ Civil Engineering Department, Semarang University, Indonesia
}

\begin{abstract}
Traffic jams are a common phenomenon in Indonesia's big cities due to the proliferation of private vehicles. The resulting air pollution directly threatens public health and urban quality of life. This research is to identify and analyze air pollution levels and forecast the potential to improve air quality by developing mass public transportation. This research employs the dust sampler method to measure the air pollution levels and calculate traffic volume, while the simulation method is used to analyze the data. The results show that the air pollution levels detected exceed the air quality thresholds established by regulations in the Decision by the Minister of Health and Environment. Traffic jam levels indicated by the Degree of Saturation (SD) were determined to be, on average, $>0.75$. The simulation results show that by changing modes of transportation traffic jam levels decrease, ranging from 0.2201 to 0.291 (DS), and air pollution decreases. Specifically, nitrogen oxides (NOx) are reduced by $48.19 \%$; sulfur dioxide $\left(\mathrm{SO}_{2}\right)$ is reduced by $51.77 \%$; particulate matter $(\mathrm{PM})$ is reduced by $29.86 \%$; lead $(\mathrm{Pb})$ is reduced by $52.22 \%$; and carbon monoxide $(\mathrm{CO})$ is reduced by $52.15 \%$. This research suggests the mass public transportation planning should be implemented.
\end{abstract}

Keywords: mass public transportation, simulation method, air pollution

\section{Introduction}

Traffic jams have become a common phenomenon in Indonesia's largest cities, resulting in elevated levels of air pollution that decrease air quality and have a detrimental effect on quality of life for the inhabitants $[2,3,6,11]$. Research on the correlation between air pollution and modes of transportation was conducted in five big city areas in Indonesia, including Semarang, Surabaya, Medan, Jakarta, and Bandung [12]. The research shows that $70 \%$ of the air pollution comes from the transportation sector, in particular caused by the use of private vehicles which greatly exceed the number of mass transit vehicles $[1,6]$. Traffic congestion not only degrades air quality, which negatively impacts health $[5,8,10]$, but also contributes to driver frustration and stress [6]. The goals of this research are: 1) identify the sources and levels of air pollution detected in the research areas; 2) analyze modifications to mass public transportation in relationship to city characteristics; and 3)

\footnotetext{
*Corresponding author: ismiyati_hs@yahoo.com
} 
examine the effects of transportation modifications on diminished air quality, that is, where air pollution has exceeded the air quality gold standard limits (threshold). This research employs a dust sampler to measure the air pollution level and calculate traffic volume, while the simulation model is utilized to analyze the data. Some previous research includes a study conducted by Wibowo [14] on air pollution emitted from vehicles entitled "Pencemaran Udara Akibat Emisi Gas Buang Kendaraan Bermotor" (Air Pollution Resulted from the Vehicles' Exhaust Gas Emission) discuss one substance released by the vehicles' combustion, that is, carbon dioxide gas $\left(\mathrm{CO}_{2}\right)$, which negatively impacts climate change and human life. In addition, research $[5,8,10]$ on gas dispersal patterns of nitrogen dioxide $\left(\mathrm{NO}_{2}\right)$ in the northern part of Semarang city which studied the area's ambient air quality was conducted due to the dangerous effects of $\mathrm{NO}_{2}$ on human health such as respiratory disorders $[5,8$, and 10$]$. These research results include three pertinent factors. First, the amount of $\mathrm{NO}_{2}$ was determined to equal 0.001445 ton/year. The transportation sector was the source of the majority of the $\mathrm{NO}_{2}$ emissions $(91.68 \%)$, followed by the industrial sector $(8.31 \%)$, and finally the domestic sector $(0.01 \%)$. Second, the conversion program simulation results show that the constant is 0.0881 . Third, the highest ambient concentration of $\mathrm{NO}_{2}$, approximately $300 \mu \mathrm{g} / \mathrm{m}^{3}$, was detected in the Tambakrejo area. This concentration is deemed unsafe for human health since it exceeds the gold standard limits for air quality which is $150 \mu \mathrm{g} / \mathrm{m}^{3}$ [5]. Based on the findings of these three studies, the researchers developed a method to explore if it would be possible to significantly reduce air pollution levels by exchanging small capacity vehicles, such as motorcycles and private cars, for larger capacity mass public transportation, such as the Rapid Transit Bus (in Indonesia known as $B R T$ ). The conclusion was that increased use of mass transportation instead of private vehicles will not only decrease pollution levels, but also reduce traffic congestion and gridlock. It is hoped that this study of air pollution levels may provide assistance to the Semarang City government in order to make and implement urban transportation plans, ultimately resulting in an environmentally-friendly city.

\section{Research method}

This research employed the Dust Sampler method to directly measure the air pollution in three research locations: location 1 in Ngesrep, location 2 in Sumurboto, and location 3 in Srondol. The initial samples were taken in Ngesrep because the traffic flows from the city's outlying areas into downtown, connecting residential areas with Diponegoro University. The air pollution measurement is compared with traffic volume calculations and observations of the number of vehicles passing through those three research locations. The research analytical method is conducted by simulating changes in transportation modes, with some scenarios assuming movements from private vehicles such as motorcycles and cars to big buses with the capacity of 100 passengers based on the results of the research phase presented in Figure 1. 


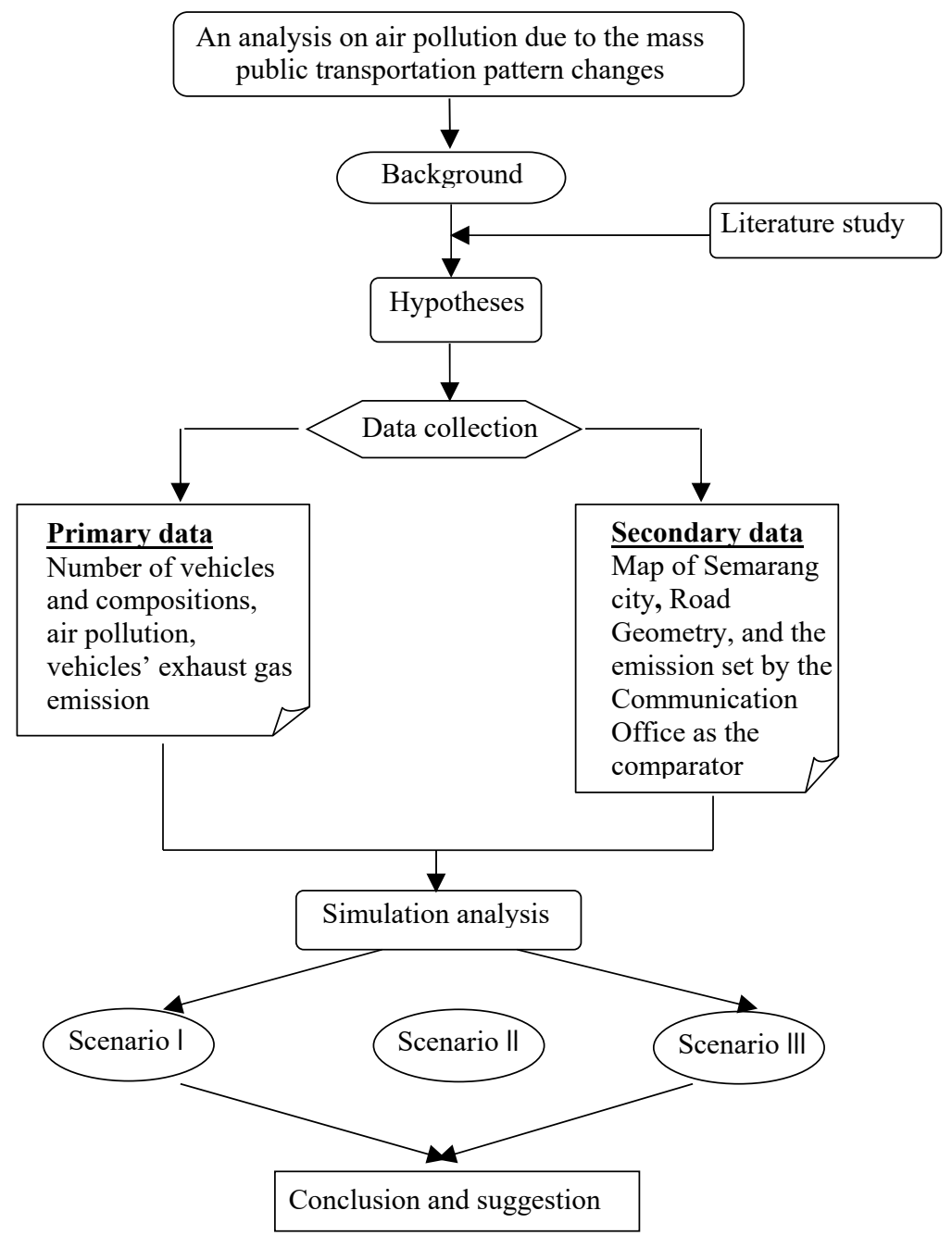

Fig. 1. Research Method

\section{Analysis and discussion}

\subsection{General description of Semarang city}

Semarang is the capital city of Central Java, on the North Coast Road which connects the city to West and East Java, and linked to Surakarta and Jogjakarta in the south. With this convenient highway access as well as a port and harbor at Tanjung Emas, Semarang has become a busy industrial city with a strategic trading sector. Semarang covers $373.7 \mathrm{~km}^{2}$ and is located at latitude $6^{\circ} 58^{\prime} 0^{\prime \prime}$ South and longitude $110^{\circ} 25^{\prime} 0^{\prime \prime}$ East. Semarang's eastern area consists of lowlands with a ground slope of ranging from $0 \%$ to $2 \%$, where it borders the Java Sea. Meanwhile, the southern sector consists of mountainous areas, and the ground slope varies from $2 \%$ to $-4 \%$. With its geographical advantages, it is not surprising that Semarang has developed into an industrial and trading city, but because of its public and 
private universities Semarang has also become a City of Students. Thus, identifying the types of activities commuters are engaged in is also significant, as demonstrated by the 3 research locations presented in Figure 2(a), 2(b).

\subsection{Traffic description at research locations}

Since Semarang is a booming trade and industrial city which creates opportunities for a great many employees, Semarang attracts an influx of people carrying out a wide variety of activities, which in turn results in significant increases in traffic volume. As people's needs for mobility all coincide at peak times, traffic jams are seemingly unavoidable. Consequently, exhaust gas emissions of vehicles stuck in gridlock may contribute more to pollution levels than those emitted by moving vehicles. Based on the observation points, the vehicle traffic in Semarang City, especially in Jl. Setiabudi and Jl. Ngesrep Timur, can be categorized as extremely heavy because these two roads provide the main access from the Southern areas to the central city and residential areas around Tembalang and the Diponegoro University campus. Traffic observations were conducted at 3 observation points: observation point 1 was located at Jl. Setiabudi in front of Toko Ada (Ada Shopping Centre) leading to the central city and Ungaran; observation point 2 was located at the Diponegoro Statue three-way junction leading from and to Diponegoro University Campus; and observation point 3 was located at Jl. Setiabudi in the Gombel area.

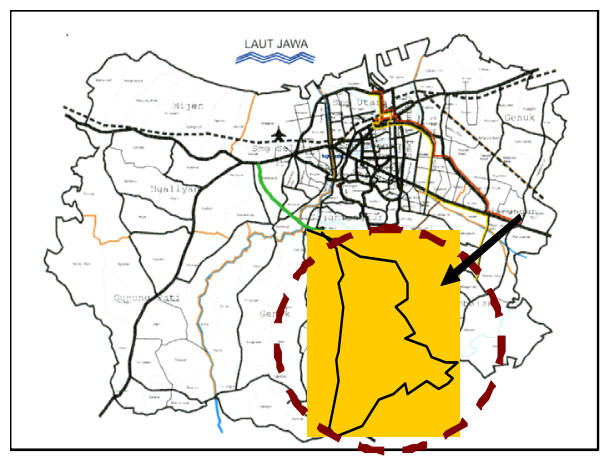

(a)

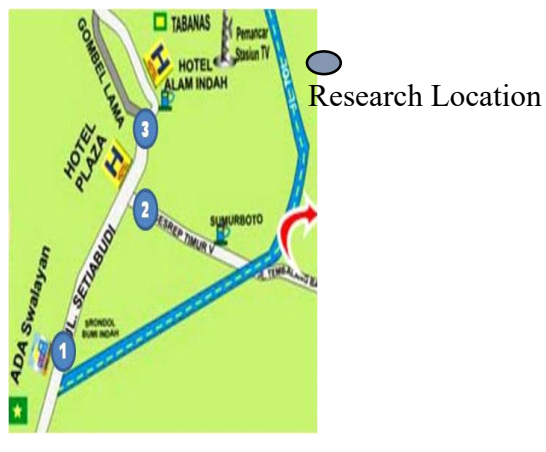

(b)

Fig. 2. (a) Map of Semarang City and (b) Research Location

\subsection{Traffic description at Setiabudi road, Semarang as research location 1}

The traffic volume observation results for Jl. Setiabudi at observation point 1 , in front of Toko Ada (Ada Shopping Centre) from both directions, Ungaran and Semarang downtown. From the research location 1 at Jl. Setiabudi as presented in Figure 2 (a) and 2 (b), the observation results show that the traffic flow in mornings, afternoons and late afternoons is dominated by motorcycles and private vehicles. The morning Peak Hour starts at $7.30-$ 7.40 a.m. with 1695 total vehicles (994 passenger car units) consisting of 232 private vehicles, 1416 motorcycles, 33 city transports, 8 city buses and 6 trucks, which, when compared to roadway capacity, generates a value for the Degree of Saturation (DS) = 1.0534. The afternoon Peak Hour starts at 12.20 - 12.30 p.m. with 1025 total vehicles (657 passenger car units) consisting of 231 private vehicles, 751 motorcycles, 29 city transports, 8 city buses and 6 trucks, which sets the value for the Degree of Saturation (DS) $=0.669$. This indicates a level of congestion already exists, with a high potential for traffic jam conditions to form. The peak hour in the late afternoon starts at $4.50-5$ p.m. at the time 
when people all leave their offices. There are 1581 total vehicles (943 passenger car units) consisting of 254 private vehicles, 1289 motorcycles, 26 city transports, 9 city buses and 3 trucks, with the value for the Degree of Saturation $(\mathrm{DS})=0.9256$. This indicates that traffic jams have already been a factor during the late afternoon peak hours.

\subsection{Traffic description at Diponegoro statue three-junction as research location 2}

The traffic volume observation results at the Diponegoro Statue three-way junction, observation point 2 leading to the Diponegoro University campus, the traffic conditions in the morning, afternoon and late afternoon are dominated by motorcycles and private vehicles. The morning peak hour starts at $7.50-8$ a.m. with 697 total vehicles (397 passenger car units) consisting of 78 private vehicles, 602 motorcycles, 15 city transports, 2 trucks and no buses, thus obtaining the value for the Degree of Saturation (DS) $=0.8595$. The afternoon peak hour starts at $12.50-1$ p.m. with 656 total vehicles consisting of 127 private vehicles, 513 motorcycles, 6 city transports, 6 city buses and 4 trucks, setting the value for the Degree of Saturation (DS) $=0.8529$. This indicates a level of congestion high enough for traffic jams to be forming. The late afternoon peak hour starts at $4.20-4.30$ p.m. coinciding with the end of people's working hours, with 795 total vehicles consisting of 93 private vehicles, 684 motorcycles, 12 city transports, 3 buses and 3 trucks, obtaining a value for Degree of Saturation $(D S)=0.9916$. This indicates that traffic jams have occurred during the late afternoon peak hours.

\subsection{Traffic description at Gombel road, Semarang as research location 3}

The traffic volume observation results at observation point 3, starting from Jl, Setiagydi (Diponegoro Statue) to Gombel Hill. At the research location 3, traffic conditions in the morning, afternoon and late afternoon are dominated by motorcycles and private vehicles. The morning peak hour starts at 7.30 - 7.40 a.m. with 1942 total vehicles (1159 passenger car units) consisting of 322 private vehicles, 1581 motorcycles, 24 city transports, 12 buses and 3 trucks, so the obtained value for the Degree of Saturation (DS) $=0.7548$. The afternoon peak hour starts at 12.50 - 1 p.m. with 1485 total vehicles $(952$ passenger car units) consisting of 368 private vehicles, 1080 motorcycles, 24 city transports, 10 city buses and 3 trucks, setting the value for the Degree of Saturation $=0.6664$. It indicates that traffic jams have already taken place. Meanwhile, the late afternoon peak hour starts at $05.20-$ 05.30 p.m. as people's working hours come to an end, with 2065 total vehicles (1229 passenger car units) consisting of 306 private vehicles, 1701 motorcycles, 29 city transports, 27 city buses and 2 trucks, setting the value for the Degree of Saturation (DS) = 0.8268 . This indicates that traffic jams have already taken place during the late afternoon peak hours.

\section{Air pollution analysis}

\subsection{Air pollution measurement results at 3 research locations}

At those three observation points, a Dust Sampler test was employed to measure the pollution level for 2 days, in conjunction with the traffic survey. Measurements were taken at $7.30-8.30$ a.m. in the morning, 11 a.m. -12 p.m. at midday/early afternoon, and $4-5$ p.m. in the late afternoon. These measurements indicate that the ambient air pollution level, 
especially in regard to the $\mathrm{CO}$ parameter, has exceeded the ambient air quality standards limit, or in other words, is above the air pollution tolerance standard. The Dust Sampler test observation results are presented in Table 1 and Table 2.

Table 1. Dust Sampler Test Observation Results on Air Pollution Level (Day-1: May 11, 2015)

\begin{tabular}{|c|c|c|c|c|c|}
\hline \multirow{4}{*}{ Survey time } & \multicolumn{5}{|c|}{ Pollution observation } \\
\hline & $\mathrm{NO2}$ & SO2 & PM & $\mathbf{P b}$ & $\mathrm{CO}$ \\
\hline & \multicolumn{5}{|c|}{ Air pollution level } \\
\hline & $100 \mu \mathrm{g} / \mathrm{m}^{3}$ & $365 \mu \mathrm{g} / \mathrm{m}^{3}$ & $150 \mu \mathrm{g} / \mathrm{m}^{3}$ & $2 \mu \mathrm{g} / \mathrm{m}^{3}$ & $40,000 \mu \mathrm{g} / \mathrm{m}^{3}$ \\
\hline \multicolumn{6}{|l|}{ Survey point 1} \\
\hline 7-9 a.m. & 23.065 & 24.363 & 105.224 & 0.002 & 101,867 \\
\hline 11 a.m.-1 p.m. & 22.735 & 36.484 & 218.854 & 0.046 & 84,864 \\
\hline 4-6 p.m & 21.875 & 36.484 & 218.854 & 0.046 & 127,644 \\
\hline \multicolumn{6}{|l|}{ Survey point 2} \\
\hline 7-9 a.m. & 15.970 & 26.310 & 149.513 & 0.031 & 77,968 \\
\hline 11 a.m.-1 p.m. & 13.681 & 14.827 & 154.902 & 0.032 & 60,142 \\
\hline 4-6 p.m & 17.946 & 19.123 & 135.924 & 0.038 & 89,770 \\
\hline \multicolumn{6}{|l|}{ Survey point 3} \\
\hline 7-9 a.m. & 27.002 & 8.905 & 318.905 & 0.066 & 222,592 \\
\hline 11 a.m.-1 p.m. & 25.955 & 40.049 & 111.111 & 0.023 & 161,059 \\
\hline 4-6 p.m & 17.383 & 21.288 & 171.171 & 0.036 & 231,966 \\
\hline
\end{tabular}

Source: [4]

Table 2. Dust Sampler Test Observation Results on Air Pollution Level (Day 2: May 13, 2015)

\begin{tabular}{|c|c|c|c|c|c|}
\hline \multirow{4}{*}{ Survey time } & \multicolumn{5}{|c|}{ Pollution observation } \\
\hline & NO2 & SO2 & PM & $\mathbf{P b}$ & $\mathrm{CO}$ \\
\hline & \multicolumn{5}{|c|}{ Air pollution level } \\
\hline & $100 \mu \mathrm{g} / \mathrm{m}^{3}$ & $365 \mu \mathrm{g} / \mathrm{m}^{3}$ & $150 \mu \mathrm{g} / \mathrm{m}^{3}$ & $2 \mu \mathrm{g} / \mathrm{m}^{3}$ & $40,000 \mu \mathrm{g} / \mathrm{m}^{3}$ \\
\hline \multicolumn{6}{|l|}{ Survey point 1} \\
\hline 7-9 a.m. & 20.431 & 88.259 & 195.113 & 0.040 & 196.914 \\
\hline 11 a.m.-1 p.m. & 19.586 & 72.256 & 101.961 & 0.021 & 113.343 \\
\hline 4-6 p.m & 18.602 & 70.794 & 133.333 & 0.028 & 167.728 \\
\hline \multicolumn{6}{|l|}{ Survey point 2} \\
\hline 7-9 a.m. & 16.388 & 20.089 & 434.654 & 0.090 & 97.035 \\
\hline 11 a.m.-1 p.m. & 17.038 & 12.905 & 274.074 & 0.057 & 80.377 \\
\hline 4-6 p.m & 22.210 & 39.783 & 277.193 & 0.058 & 94.126 \\
\hline \multicolumn{6}{|l|}{ Survey point 3} \\
\hline 7-9 a.m. & 14.597 & 16.462 & 200.619 & 0.041 & 221.461 \\
\hline 11 a.m.-1 p.m. & 33.873 & 19.989 & 223.558 & 0.046 & 161.833 \\
\hline 4-6 p.m & 14.934 & 16.641 & 130.308 & 0.027 & 238.844 \\
\hline
\end{tabular}

\subsection{Air pollution simulation results due to the mass public transportation changes}

The pollution level observation results conducted using the Dust Sampler device show that the current air pollution level exceeds the ambient air quality standards limit. Because traffic has continued to increase year by year, it is obvious that the air pollution level may continue to increase as well. Thus, it is necessary to implement a variety of efforts in order to reduce/slow down the excessive air pollution, especially those pollutants attributed to vehicular exhaust gas emissions. 


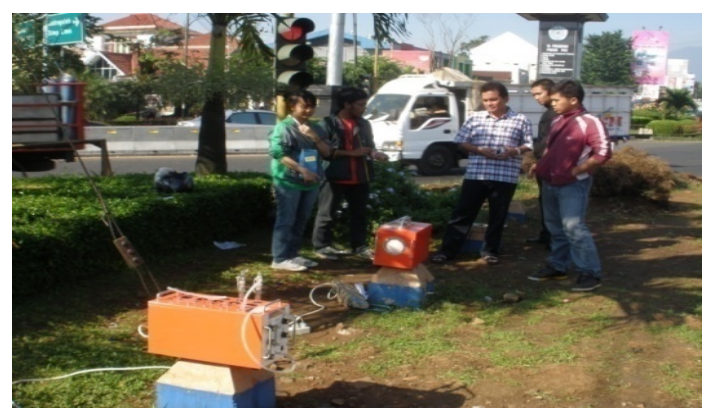

Fig. 6. Air Pollution Level Measurement using Dust Sampler Device

Source: Napitulu,B, 2017

The method used to simulate the air pollution level is through changes or reductions based on the following assumptions: each motorcycle has capacity for 2 passengers; private cars each have 4 passengers; city transport carries 8 passengers; and BRT (Rapid Transit Bus) has capacity for 100 passengers. The total passengers in each vehicle are based on the previous observations, while those of $B R T$ are determined based on vehicles commonly used in the areas of the city where it is necessary/desirable to decrease or reduce the air pollution level. The simulation is conducted with multiple scenarios in order to determine the best possible way to reduce air pollution levels and thus successfully reach the ambient air quality standards, below the limits as regulated by the Decision from the Ministry of Health and Environment [7], and additionally, as a control to measure the Degree of Saturation (DS) on roads. The results are presented in Table 3.

\subsection{Description of simulation results}

The description of the simulation results showing the potential reduction of pollution levels and traffic jam controls based on those 3 scenarios are presented in Table 3, Table 4, and Table 5.

\subsubsection{Scenario-1}

In Scenario 1, it is assumed that $50 \%$ of all motorcycle users will shift to using the mass public transportation/BRT, which has capacity for 100 passengers, and results are presented in Table 3.

Table 3. Simulation Results of Scenario 1

\begin{tabular}{|c|c|c|c|c|}
\hline $\begin{array}{c}\text { Para } \\
\text { meter }\end{array}$ & $\begin{array}{c}\text { The Existing } \\
\text { Condition of } \\
\text { Pollution Level } \\
\left(\boldsymbol{\mu g} / \mathbf{m}^{3}\right)\end{array}$ & $\begin{array}{c}\text { Pollution Level based } \\
\text { on Simulation Result } \\
\left(\boldsymbol{\mu g} / \mathbf{m}^{\mathbf{3}}\right)\end{array}$ & $\begin{array}{c}\text { Pollution Level } \\
\text { Reduction } \\
\left(\boldsymbol{\mu g} / \mathbf{m}^{\mathbf{3}}\right) \mathbf{\%} \%\end{array}$ & $\begin{array}{c}\text { Traffic Jam } \\
\text { Control } \\
\text { Level } \\
(\mathbf{D S})\end{array}$ \\
\hline $\mathrm{NO} 2$ & 33.387 & 35.340 & $1.953 / 55.85 \%$ & -- \\
\hline $\mathrm{SO} 2$ & 88.259 & 39.445 & $48.814 / 55.31 \%$ & -- \\
\hline $\mathrm{Pm}$ & 434.654 & 254.634 & $180.020 / 41.42 \%$ & -- \\
\hline $\mathrm{Pb}$ & 0.090 & 0.054 & $0.036 / 40.00 \%$ & -- \\
\hline $\mathrm{CO}$ & 238.844 & 239.844 & $1.000 / 0.042 \%$ & -- \\
\hline $\mathrm{DS}$ & -- & -- & -- & 0.3728 \\
\hline
\end{tabular}

Source: [4] 


\subsubsection{Scenario-2}

In Scenario 2, it is assumed that $60 \%$ of all motorcycle users will shift to an alternative mode of transportation. This is further defined by assuming $40 \%$ will utilize mass public transportation/BRT with the capacity of 100 passengers while $20 \%$ will move to city transport. In addition, trucks are restricted from using the roads as pass-throughs (all trucks prohibited except for local deliveries). The results are presented in Table 4

Table 4. Simulation Results of Scenario 2

\begin{tabular}{|c|c|c|c|c|}
\hline Parameter & $\begin{array}{c}\text { The Existing Condition } \\
\text { of Pollution Level } \\
\left(\mu \mathrm{g} / \mathrm{m}^{3}\right)\end{array}$ & $\begin{array}{c}\text { Pollution Level } \\
\text { based on } \\
\text { Simulation Result } \\
\left(\mu \mathrm{g} / \mathbf{m}^{3}\right)\end{array}$ & $\begin{array}{c}\text { Pollution } \\
\text { Level } \\
\text { Reduction } \\
\left(\mu \mathrm{g} / \mathbf{m}^{3}\right) / \%\end{array}$ & $\begin{array}{c}\text { Traffic Jam } \\
\text { Control } \\
\text { Level } \\
\text { (DS) }\end{array}$ \\
\hline $\mathrm{NO} 2$ & 33.387 & 21.615 & $\begin{array}{l}11.772 / \\
35.26 \%\end{array}$ & -- \\
\hline $\mathrm{SO} 2$ & 88.259 & 48.444 & $\begin{array}{l}39.815 / \\
45.11 \%\end{array}$ & -- \\
\hline $\mathrm{Pm}$ & 434.654 & 304.864 & $\begin{array}{l}129.79 / \\
29.86 \% \\
\end{array}$ & -- \\
\hline $\mathrm{Pb}$ & 0.090 & 0.049 & $\begin{array}{l}0.041 / \\
45.56 \% \\
\end{array}$ & -- \\
\hline $\mathrm{CO}$ & 238.844 & 133.333 & $\begin{array}{c}105.511 / \\
44.18 \%\end{array}$ & -- \\
\hline DS & -- & -- & -- & 0.4271 \\
\hline
\end{tabular}

Source: [4]

\subsubsection{Scenario 3}

In Scenario 3, it is assumed that $60 \%$ of all motorcycle users plus $50 \%$ of all private car users will move to mass public transportation/BRT vehicles which each have a capacity of 100 passengers. Based on that assumption, the resulting reductions in the pollution level and the level of control exerted to prevent traffic jams are presented in Table 5.

Table 5. Simulation Results of Scenario -3

\begin{tabular}{|c|c|c|c|c|}
\hline Parameter & $\begin{array}{c}\text { The Existing } \\
\text { Condition of } \\
\text { Pollution Level } \\
\left(\boldsymbol{\mu g} / \mathbf{m}^{\mathbf{3}}\right)\end{array}$ & $\begin{array}{c}\text { Pollution } \\
\text { Level based } \\
\text { on } \\
\text { Simulation } \\
\text { Result } \\
\left(\boldsymbol{\mu g} / \mathbf{m}^{\mathbf{3}}\right)\end{array}$ & $\begin{array}{c}\text { Pollution Level } \\
\text { Reduction } \\
\left(\boldsymbol{\mu g} / \mathbf{m}^{\mathbf{3}}\right) / \%\end{array}$ & $\begin{array}{c}\text { Traffic Jam } \\
\text { Control Level } \\
(\mathbf{D S})\end{array}$ \\
\hline $\mathrm{NO} 2$ & 33.387 & 17.298 & $16.089 / 48.19 \%$ & -- \\
\hline $\mathrm{SO} 2$ & 88.259 & 42.563 & $45.696 / 51.77 \%$ & -- \\
\hline $\mathrm{Pm}$ & 434.654 & 304.864 & $129.29 / 29.86 \%$ & -- \\
\hline $\mathrm{Pb}$ & 0.090 & 0.043 & $0.047 / 52.22 \%$ & -- \\
\hline $\mathrm{CO}$ & 238.844 & 114.289 & $124.555 / 52.15 \%$ & -- \\
\hline $\mathrm{DS}$ & -- & -- & -- & 0.2931 \\
\hline
\end{tabular}

Source: [4]

Based on those 3 scenarios, the analytical results show that the most advantageous model is the simulation analysis for scenario 3, which provides the highest reduction of air pollution levels. 


\section{Conclusion and recommendation}

\subsection{Conclusion}

Based on the preliminary observations and the simulated analytical results conducted with 3 scenarios and 3 observation points (roads), it can be concluded that:

1. The air pollution levels as previously observed, consisting of $\mathrm{NO}_{2}=13.681$ to 33.873 $\mathrm{ug} / \mathrm{m}^{3}, \mathrm{SO}_{2}=8.905$ to $88.259 \mathrm{ug} / \mathrm{m}^{3}, \mathrm{PM}=101.961$ to $434.564 \mathrm{ug} / \mathrm{m}^{3}, \mathrm{~Pb}=0.002$ to $0.090 \mathrm{ug} / \mathrm{m}^{3}$ and $\mathrm{CO}=60.142$ to $238.844 \mathrm{ug} / \mathrm{m}^{3}$, are above the standard limits (threshold) mandated by the Ministry of Health and Environment in Decision number: Kep-35/MENLH/10/1993.

2. Based on those 3 scenarios, the analytical results show that scenario 3 is considered the most appropriate one to reduce or decrease the air pollution level by increasing the number of mass public transportation/BRT and city transport units, with the assumption that $60 \%$ motorcycle users will move to using modes of mass public transportation. Specifically, $40 \%$ of all motorcycle users will begin to use $B R T$ and $20 \%$ will move to the smaller city transports. Furthermore, it is assumed that $50 \%$ of private car users will move and use BRT. In addition, trucks are prohibited from using the roads (except for local deliveries).

3. The analytical results based on scenario 3 are presented as follows:

a. The air pollution level results from the analysis based on the simulation assumed in scenario 3, indicating $\mathrm{NO}_{2}=10.594 \mathrm{ug} / \mathrm{m}^{3}, \mathrm{SO}_{2}=18.976 \mathrm{ug} / \mathrm{m}^{3}, \mathrm{PM}=135.602$ $\mathrm{ug} / \mathrm{m}^{3}, \mathrm{~Pb}=0.032 \mathrm{ug} / \mathrm{m}^{3}$, and $\mathrm{CO}=45.813 \mathrm{ug} / \mathrm{m}^{3}$, are considerably reduced from the previous pollution level.

b. The analysis conducted based on the simulation of scenario 3 indicates the resulting value for Degree of Saturation, (DS) $=0.2201$ to 0.2931 , is lower than the DS in the previous observation which is 0.9830 to 1.038 . This demonstrates that by decreasing the total number of vehicles, traffic jams will be eliminated, which should also result in a corresponding decrease in the ambient air pollution level.

\subsection{Recommendation}

This research recommends: first, the government should consider air pollution levels when planning changes and upgrades to the transportation system, such as by providing additional public transportation services, identifying the most appropriate and convenient mass public transportation conveyances, and maximizing passenger capacity to attract the maximum number of public transportation users; second, because traffic jams are generally caused by an excessive number of private vehicles and motorcycles and thus contribute to excessive air pollution levels, the government should implement plans to increase availability of public transportation by establishing and integrating routes that simultaneously provide effective service to residential areas and reduce emissions in sectors where air pollution currently exceeds the ambient air quality standards limit. 
The researchers would like to express the gratitude to all lecturers majoring in the Transportation of Civil Engineering Master Program/Engineering Faculty for supervising this research, and the Environmental Engineering Laboratory of Diponegoro University for the air pollution measurements.

\section{References}

1. Badan Pusat Statistik (BPS) [Central Bureau of Statistics], 2016, Semarang in Figure Dalam Angka [Semarang in Figure], issued by BPS Semarang [Semarang Central Bureau of Statistics], Indonesia.

2. E.Budihardjo, 2003, Kota dan Lingkungan [City and its Environment]. Pendekatan Baru Masyarakat Berwawasan Ekologi [A New Approach of Community with Ecological Insight], ISBN 979-3330-10-4, LP3ES Indonesia.

3. Brutland Report, 1987, Sustuinable Development. University of East Anglia Norwich NRA 7TJ. UK.

4. B. Napitulu.et al., 2017.," Analisis Pencemaran Udara Akibat Perubahan Angkutan Masal [An Analysis on Air Pollution Due to the Mass Transportation Changes]", Thesis. Magister Teknik Sipil [Civil Engineering Master Program]-Undip [Diponegoro University], Semarang, Indonesia.

5. H. Mochtar and S Huboyo, H, 2006.," Pola Penyebaran Gas $\mathrm{NO}_{2}$ Di Udara Ambien Kawasan Utara Kota Semarang Pada Musim Kemarau Menggunakan Program ISCST3 [Air Distributional Patterns of $\mathrm{NO}_{2}$ on The North Area Ambient in Semarang], Journal of PRESIPITASI Vol1 (19-24), 2006 ISSN 1907-187X, FT-Undip, Semarang.

6. I. Ismiyati \& F. Hermawan, 2018.," Lifestyle as an Influential Factor to Urban Mobility Transport: a Case Study of Semarang City, Indonesia. IOP Conf. Ser.: Earth Environ. Sci. 123012020.

7. Keputusan Menteri Lingkungan Hidup [The Decision of the Minister of Environment] Number: Kep-41/MENLH/4/2014, on “Ambang Batas Emisi Gas Kendaraa Bermotor [Motor-Vehicles' Exhaust Emission]", issued by the State Secretariat, 2014.

8. M. Sorensen et al., 2015: Exposure to long-term air pollution a road traffic noise in relation to cholesterol: A Cross-sectional study; Environment International 85 (2015) 238-234. Journal homepage: www.elsevier.com/locate/envit

9. M. Fahri Iskandar, 2013. Dampak Asap Kendaraan Bermotor Terhadap Lingkungan [The Influence of Motor Vehicles' Emission on Environment].

10. N. Roswall. et al., 2017: Long-Term Residential road traffic noise and $\mathrm{NO}_{2}$ Expsure in relation to risk of incident myocardial infarction (MI) - A Denish Cohrt Study.

Environmental research 156(2017) 80-86; journal homepage: www.elsevier.com/locate/envit

11. R. Rahma, 2015. Pencemaran Udara Akibat Polusi Yang Ditimbulkan Kendaraan Bermotor [Air Pollution Resulted from Motor Vehicles]. https://rahmariska.wordpress.com/2015/06/120/makalah-polusi-udara

12. R.Rudatin et al., 2006, Penelitian Pencemaran Udara [An Air Pollution Research]. https://id.scrib.com/doc/252129854

13. K.Schripper, 2006, Pembangunan Berkelanjutan [Sustainable Development], Publisher: Erlangga Indonesia

14. W.Ari,2013., Pencemaran Udara Akibat Kendaraan Bermotor [Air Pollution Resulted from Motor Vehicles], https://ariefboting/blogspot.com/2013/10/pencemaran-udaraakibat-emisi-gas-buang. 